\title{
Birth Intervals among Multiparous Women in Indonesia
}

\author{
Jarak Kelahiran pada Perempuan Multipara di Indonesia
}

\author{
Dini Kurniawati*, Sabarinah Prasetyo**
}

*Budi Kemuliaan Hospital, Jakarta, Indonesia, **Biostatistics and Population Studies Departement, Faculty of
Public Health, Universitas Indonesia, Depok, Indonesia

DOI: http://dx.doi.org/10.21109/kesmas.v10i4.839

\begin{abstract}
Maternal mortality rate and infant mortality rate in Indonesia are currently high. One of factors causing the high risk of maternal and infant mortality is too short birth intervals. This study aimed to learn determinants of birth intervals among multiparous women in Indonesia. This study used data from the Indonesia Demographic and Health Survey 2012 with 9,945 multiparous women. The data was analyzed using Mann Whitney, Kruskal Wallis and logistic regression tests. Median of birth intervals was 62 months and $22.8 \%$ women had birth interval less than three years. Results showed that determinants of birth intervals included maternal education, the last age of childbirth, ideal family size, the use of contraception, infant mortality records and survival of preceding child ( $p$ value $<0.05$ ). The age of childbirth was a major risk factor of too short birth intervals. It needs the improvement of communication, information and education regarding maturation of age for marriage, ideal number of children as well as the increase of contraceptive use in order to increase optimum birth intervals.

Keywords: Birth intervals, infant mortality, multiparous
\end{abstract}

\begin{abstract}
Abstrak
Angka kematian ibu dan angka kematian bayi di Indonesia masih tinggi. Salah satu faktor yang menyebabkan tingginya risiko kematian pada ibu dan bayi adalah kelahiran terlalu dekat. Penelitian ini bertujuan untuk mempelajari determinan jarak antarkelahiran pada perempuan multipara di Indonesia. Penelitian ini menggunakan data Survei Demografi Kesehatan Indonesia tahun 2012 pada 9.945 perempuan multipara. Analisis data menggunakan uji Mann Whitney, Kruskal Wallis, dan regresi logistik. Median jarak antarkelahiran sebesar 62 bulan dan 22,8\% perempuan memiliki jarak antarkelahiran kurang dari tiga tahun. Hasil menunjukkan determinan jarak antarkelahiran pendek meliputi pendidikan ibu, usia terakhir melahirkan, ukuran ideal keluarga, pemakaian kontrasepsi, riwayat kematian anak, dan
\end{abstract}

kelangsungan hidup anak sebelumnya (nilai $p<0,05$ ). Usia melahirkan merupakan faktor yang paling berisiko terhadap jarak kelahiran terlalu dekat. Diperlukan peningkatan komunikasi, informasi, dan edukasi mengenai pendewasaan usia pernikahan, jumlah anak ideal serta peningkatan pemakaian kontrasepsi dalam upaya meningkatkan jarak antarkelahiran optimum.

Kata kunci: Jarak kelahiran, kematian bayi, multipara

\section{Introduction}

Infant mortality rate (IMR) and maternal mortality rate (MMR) are indicators of national health standards. MMR and IMR are also targets determined in the Millennium Development Goals (MDGs). ${ }^{1}$ According to World Health Organization (WHO), the IMR is the number of infants died before the age of one year per 1,000 live births. Meanwhile, MMR is maternal death that occur during pregnancy, childbirth, or within 42 days of postnatal period with causes related directly or indirectly to pregnancy per 100,000 live births. In Indonesia, maternal mortality is one of the highest in Asia. Based on the report from Indonesia Demographic and Health Survey (IDHS) in 2012, it was recorded that MMR reached up to 359 per 100,000 live births. This number increased compared to the IDHS in 2007 which recorded MMR as many as 228 per 100,000 live births. ${ }^{2}$

In the world, 19,000 children died every day in 2011.

Correspondence: Dini Kurniawati, Budi Kemuliaan Hospital, Budi Kemuliaan Street No.25 Central Jakarta 10110, Indonesia, Phone: +6221-3842828, e-mail: dhinikurnia@gmail.com/dini.kurniawati01@alumni.ui.ac.id 
According to The United Nations Children's Fund (UNICEF)'s report in 2012, IMR in Asia was amounted to 34 per 1,000 live births. ${ }^{3}$ In Indonesia, IMR was steadily declining (but the decline was insignificant). IMR decreased from 35 per 1,000 live births in 2004 to 34 per 1,000 live births in 2007 and reached 32 per 1,000 live births in $2012 .^{2}$ When compared to other countries in Asia whose economic conditions are not too different with Indonesia, Indonesia is still lagging. In 2012, UNICEF reported that in Philippines, IMR was 20 per 1,000 live births, while in Malaysia IMR was 6 per 1,000 live births. ${ }^{3}$ Indonesia still needs to reduce infant mortality by $40 \%$ to achieve the MDGs 2015 that is 23 per 1,000 live births.

Efforts to reduce maternal mortality and infant mortality have been performed through family planning programs by The National Family Planning Coordinating Board (BKKBN). Through family planning programs, various programs are presented in thinning or birth control. ${ }^{4}$ Birth interval is useful to reduce the high risk pregnancy. By thinning the birth, the mother has a chance to regain her health before next conception. Healthy pregnancy will also have an impact on fetal development in which fetus develops healthy.

Birth intervals control action in Indonesia has not been optimal. IDHS 2012 showed the birth intervals in Indonesia in which $4.4 \%$ of births had intervals less than 18 months, less than 24 months $(10.5 \%)$, less than 36 months $(25 \%)$ after the previous birth. Median of birth intervals was 60.2 months in 2012 which increased compared to 54.6 months in 2007. IDHS 2012 also showed that child mortality risk is three times higher on children born with birth intervals less than two years compared to children born with intervals of four years or more. Neonatum death, post-neonatum death, infant death and toddler death are twice as high for children born with birth intervals less than two years compared to children born with intervals of four years or more. ${ }^{2}$

Birth interval is a period between two live births from a woman. ${ }^{5}$ According to the United States Agency for International Development (USAID), the optimum birth interval limit is the limit of time between births which produce the best health outcomes for pregnancy, mothers, newborns, and the all families. ${ }^{6}$ Study conducted by Rasheed and Dabal indicated that the optimum interval between the birth period was between three to five years. ${ }^{7}$

According to Conde-Agudelo and Belizan, too short birth intervals may increase the risk of toxemia, anemia, malnutrition, bleeding and maternal death. ${ }^{8}$ The too short interval is also associated with an increasing risk of abortion. In addition, too short birth intervals also increases the risk of low birthweight (LBW) incidence and infant death. ${ }^{9-11}$ Waiting up to 36 months or more for the next pregnancy can reduce the risk of morbidity and infant mortality. 12

The still high prevalence of short birth intervals in Indonesia was influenced by various factors. According to Davis Blake, social factors and the behavioral factors influenced variable birth intervals through intermediate variables. The total of intermediate variables was 11 variables and these variables were classified into three broad categories including the variable intercourse, variable conception, and the variable gestation. ${ }^{13}$

A multiparous woman is a woman who has given birth more than once. ${ }^{14}$ Among multiparous women, birth interval of each child with the preceding birth can be seen. Based on the data above, it is necessary to conduct study on factors related to birth intervals among multiparous women in Indonesia.

\section{Method}

This study used secondary data from IDHS in 2012 with a cross-sectional study design. Demographic and Health Survey 2012 conducted by the Central Statistics Agency (BPS) in collaboration with BKKBN, Ministry of Health and USAID.

Population in this study were all childbearing women in Indonesia who had records of live births and not including the firstborn. Samples were respondents noted in 2012 that met the IDHS inclusion and exclusion criteria. Inclusion criteria of this study were women at childbearing age who had records of the last live births within fiveyear period prior to the survey and not including births of the firstborn. Meanwhile, the exclusion criterion was babies born twins because twin births have 0-month birth spacing.

The minimum sample size was calculated using a formula of different proportions. The result of the calculation obtained was 5,360 respondents, meanwhile samples used from the data of IDHS were as many as 9,945 respondents. Thus, the sample examined was eligible for minimum sample size. The dependent variable was the birth intervals. While the independent variables were the maternal education, economic status, place of residence, age at the last childbirth, the number of living children, sex of the preceding birth, the ideal size of family, contraception knowledge, perspectives of husbands against contraception, the use of contraception, exclusive breastfeeding, infant mortality records, survival of the preceding birth. The data was analyzed using Mann Whitney test, Kruskal Wallis, and logistic regression test.

\section{Results}

The average birth intervals was 69.02 months with standard deviations 40.7 months. Median birth intervals in this study was 62 months with the most birth interval of 25 months. The median value of the confidence inter- 
Table 1. Relation between Birth Intervals and Demographic Characteristics

\begin{tabular}{llllll}
\hline \multirow{2}{*}{$\begin{array}{l}\text { Demographic Characteristic } \\
\text { Variables }\end{array}$} & Category & \multicolumn{2}{c}{ Median of Birth Intervals (Months) } \\
\cline { 3 - 5 } & & Median & $\mathbf{9 5 \%}$ CI & n & p Value \\
\hline \multirow{2}{*}{ Maternal education } & High ( $\geq$ SHS) & 54 & $52-56$ & 3474 & $0.0005^{*}$ \\
& Low $(<$ SHS) & 68 & $64-69$ & 6471 & \\
Economic status & Highest & 62 & $60-64$ & 1958 & $0.0005^{*}$ \\
& Fourth & 70 & $67-72$ & 1996 & \\
& Middle & 69 & $66-71$ & 1904 & \\
& Second & 63 & $60-66$ & 1828 & \\
& Lowest & 50 & $48-52$ & 2258 & \\
Residence & Urban & 61 & $60-62$ & 4953 & 0.133 \\
Age at the last childbirth & Rural & 64 & $62-65$ & 4991 & \\
& $\leq 20$ years old & 25 & $22-32$ & 82 & $0.0005^{*}$ \\
Number of living children & $20-35$ years old & 59 & $59-60$ & 7441 & \\
& $\geq 35$ years old & 78 & $75-80$ & 2421 & \\
& $\leq 2$ & 64 & $62-65$ & 5512 & $0.0005^{*}$ \\
& $>2$ & 60 & $59-62$ & 4432 & \\
\hline
\end{tabular}

*) Significant at p value $<0.05$ Mann Whitney or Kruskal Wallis test

val $(95 \% \mathrm{CI})$ indicated a value between 61 to 63 months. It could also be concluded that the birth interval data distribution was asymmetrical or did not follow normal distribution. After categorized, respondents who had short birth intervals (less than 36 months) was $22.8 \%$.

Results showed that median birth intervals was lower among respondents with higher education (54 months). Based on the economic level, the lowest median birth intervals was found among respondents with the low economic level while the highest median birth intervals was among respondents with the fourth economic level (70 months). Median birth intervals of respondents who lived in rural and urban areas were similar, respectively 61 months and 64 months. Moreover, Table 1 showed median birth intervals increased by age that was 25 months among respondents aged less than 20 years, 59 months among respondents aged 20 to 35 years and 78 months among respondents aged over 35 years. Median birth interval was lower on respondents with the rate of live births more than two people (60 months).

The results showed that the median birth intervals based on sex of preceding birth between male and female were same, respectively 62 months and 63 months. Median birth interval was lower on respondents with preference ideal family size more than two children (58 months) (Table 2).

Based on knowledge level, the median birth intervals between respondents who had high and low knowledge of contraception was the same at 62 months. Median birth intervals between respondents who agreed and disagreed were similar, respectively 65 months and 62 months. The lowest median birth interval was found among repondents who used traditional contraception (50 months) (Tabel 3).

Results on Table 4 showed median birth intervals was
Table 2. Relation between Birth Intervals and Family Size and Structure

\begin{tabular}{llllll}
\hline \multirow{2}{*}{$\begin{array}{l}\text { Family Size and } \\
\text { Structure Variables }\end{array}$} & Category & \multicolumn{4}{c}{ Median Birth Interval (Months) } \\
\cline { 3 - 6 } & & Median & $\mathbf{9 5 \%}$ CI & n & \multirow{2}{*}{ p Value } \\
\hline \multirow{2}{*}{ Sex of preceding birth } & Male & 62 & $60-63$ & 5188 & 0.775 \\
& Female & 63 & $62-65$ & 4756 & \\
Ideal family size & $\leq 2$ & 67 & $66-69$ & 4746 & $0.0005^{*}$ \\
& $>2$ & 58 & $57-59$ & 4266 & \\
\hline
\end{tabular}

*) Significant at $\mathrm{p}$ value $<0.05$ Mann Whitney or Kruskal Wallis test

lower on respondents who exclusively breastfed ( 57 months). Based on infant mortality records, the median birth interval was lower on respondents who had infant mortality record (47 months). Birth interval was lower on respondents with survival of preceding birth was dead (33 months).

Determinants of birth intervals included maternal education, age at the last childbirth, ideal family size, contraceptive use, infant mortality records and survival of preceding birth. Women who had the last pregnancy at the age of $<20$ years had a short birth interval of less than three years of 11.1 times $(1 / 0.09)$ times $(\mathrm{OR}=11.1$; $95 \% \mathrm{CI}=7.14$ to 16.67 ) than respondents aged between 20 - 35 years old. Respondents who had the last childbirth at the age of $<20$ years had the risk of having a short birth interval $20.0(1 / 0.05)$ times $(\mathrm{OR}=20.0$; CI $95 \%=14.29-33,33)$ times higher than respondents aged $>35$ years. Respondents who were highly educated had a risk of having a short birth interval of $1.51(1 / 0.66)$ times $(\mathrm{OR}=1.51 ; 95 \% \mathrm{CI}=1.36$ to 1.67$)$ higher than respondents with the low education level. Respondents who had the ideal family size of more than two children had the risk of having a short birth interval 1.34 times $(\mathrm{OR}=1.34 ; 95 \% \mathrm{CI}=1.21$ to 1.48$)$ higher than the ideal size of the respondents who had less family living with 
Tabel 3. Relation between Birth Intervals and Knowledge and Opinion on Contraception

\begin{tabular}{llcccc}
\hline \multirow{2}{*}{$\begin{array}{l}\text { Knowledge and Opinion } \\
\text { on Contraception }\end{array}$} & Category & \multicolumn{4}{c}{ Median Birth Intervals (Months) } \\
\cline { 3 - 6 } & & Median & $\mathbf{9 5 \%}$ CI & n & p Value \\
\hline Knowledge of contraceptive methods & High & 62 & $61-64$ & 4855 & 0.331 \\
& Low & 62 & $61-63$ & 5090 & \\
Opinion of couples using a & Agree & 65 & $64-67$ & 7312 & 0.331 \\
$\begin{array}{l}\text { contraceptive method to avoid } \\
\text { pregnancy }\end{array}$ & Disagree & 62 & $56-74$ & 138 & \\
Contraceptive use & Modern method & 66 & $25-67$ & 7132 & $0.0005^{*}$ \\
& Traditional method & 50 & $47-54$ & 467 & \\
& Not use & 53 & $51-55$ & 2345 & \\
\hline
\end{tabular}

*) Significant at $\mathrm{p}$ value $<0.05$ Mann Whitney or Kruskal Wallis test

Table 4. Relation between Birth Intervals and Biosocial Characteristics

\begin{tabular}{llllll}
\hline \multirow{2}{*}{ Biosocial Characteristics } & Category & \multicolumn{3}{c}{ Median Birth Intervals (Months) } \\
\cline { 3 - 5 } & & Median & $\mathbf{9 5 \%}$ CI & n & p Value* \\
\hline \multirow{2}{*}{ Exclusive breastfeeding } & No & 63 & $62-64$ & 282 & $0.0005^{*}$ \\
& Yes & 57 & $51-60$ & 9663 & \\
Infant mortality record & No & 64 & $63-66$ & 8519 & $0.0005^{*}$ \\
& Yes & 47 & $44-49$ & 1425 & \\
Survival of preceding birth & Living & 64 & $63-65$ & 9417 & $0.0005^{*}$ \\
& Dead & 33 & $31-37$ & 527 & \\
\hline
\end{tabular}

*) Significant at p value $<0,05$ Mann Whitney or Kruskal Wallis test

Table 5. Determinants of Birth Intervals

\begin{tabular}{|c|c|c|c|c|c|}
\hline \multirow{2}{*}{ Variable } & \multirow{2}{*}{ B } & \multirow{2}{*}{ p Value } & \multirow{2}{*}{$\operatorname{Exp}(B)$} & \multicolumn{2}{|c|}{ 95\% CI Exp (B) } \\
\hline & & & & Lower & Upper \\
\hline Maternal education & -0.420 & 0.000 & 0.66 & 0.60 & 0.73 \\
\hline Age at the last childbirth $<20$ years old & & & & 1.00 & \\
\hline Age at the last childbirth $20-35$ old & -2.447 & 0.000 & 0.09 & 0.06 & 0.14 \\
\hline Age at the last childbirth $>35$ old & -3.071 & 0.000 & 0.05 & 0.03 & 0.07 \\
\hline Ideal family size & 0.292 & 0.000 & 1.34 & 1.21 & 1.48 \\
\hline Modern contraceptive method & & & 1.00 & & \\
\hline Traditional contraceptive method & 0.308 & 0.001 & 1.47 & 1.18 & 1.83 \\
\hline Not use contraception & 0.408 & 0.000 & 1.50 & 1.35 & 1.69 \\
\hline Infant mortality records & 0.519 & 0.000 & 1.68 & 1.70 & 2.73 \\
\hline Survival of preceding birth & 0.767 & 0.000 & 2.15 & 1.43 & 1.97 \\
\hline
\end{tabular}

two children. Respondents who used traditional contraceptive method were 1.47 times $(\mathrm{OR}=1.47 ; 95 \% \mathrm{CI}=$ 1.18 to 1.83 ) more likely to have shorter birth interval than respondents who used modern contraceptives. Respondents who did not use contraception were at risk 1.50 times $(\mathrm{OR}=1.50 ; 95 \% \mathrm{CI}=1.35$ to 1.69$)$ more likely to have shorter birth intervals than respondents who used modern contraceptives. Respondents who had infant mortality records were 1.68 times $(\mathrm{OR}=1.68$; $95 \% \mathrm{CI}=1.70$ to 2.73 ) more likely to have shorter birth interval than respondents who had never experienced the death of a child. Respondents with survival of preceding birth was dead had the risk 2.15 times (OR $=2.15$; $95 \%$ $\mathrm{CI}=1.43$ to 1.97$)$ more likely to have shorter birth interval than respondents with survival of preceding birth was still living (Tabel 5).

\section{Discussion}

Respondents who were highly educated had a higher risk of having the short birth intervals in which the risk of short birth interval on high educated respondents was 1.51 higher than the low educated respondents. These results were in contrast to studies in Ethiopia where short birth intervals were more common among women with low level of education. ${ }^{15}$ Women with higher education were more likely to use contraception to space births and extend access to information and better health awareness. ${ }^{15-19}$ The difference in results was because in this study, the group of more educated women were mostly young women. This is in line with IDHS report in 2012 that showed the median birth intervals on women graduated from high school and college was lower than women who did not complete primary school and never graduat- 
ed from high school. ${ }^{2}$ Results of cross tabulation also showed that proportion of highly educated women were more at age less than 35 years old compared to the age over 35 years old.

There was a positive relation between age and birth intervals. These results were similar to studies in Spain and Iran. The older age, the higher median birth intervals. This effect was related to the process of degeneration in female fertility because of age. ${ }^{16,20-21}$ Moreover, the older age increased birth intervals due to the increasing experience and women knowledge. ${ }^{21}$ Increasing age also indicated contraceptive use as an effort to reduce the risk of pregnancy and to increase birth intervals.

Results showed the ideal proportion of children related to birth intervals. Respondents who wanted more than two children had risk of having a short birth interval 1.34 times higher than respondents who wanted a child less than or equal to two children. Studies in Iran and Tanzania showed number of children living significantly related to birth spacing. ${ }^{21,22}$ The number of children was not the desired direct variables affecting fertility, but related to the variables affecting the birth control. 23

There was a significant relation between contraceptive use and birth intervals. Respondents who used traditional contraceptives had risk 1.47 times more likely to have short birth intervals compared to respondents who used modern contraceptives. Respondents who did not use contraceptives had risk 1.50 times more likely to have short birth intervals compared to respondents who used modern contraceptives. This is in line with the prior study conducted in which contraceptive users had birth intervals longer than those who did not use contraceptives. ${ }^{15,24,25}$ This could be caused by the contraceptive effect to delay the time until the next conception. ${ }^{24}$ Bongaars theory also stated that such contraception affected directly on fertility. 26

For respondents who had infant mortality records, the percentage of short birth intervals was higher than respondents who never had infant mortality records. Results showed that respondents who had infant mortality records had the risk 1.68 times more likely to have shorter birth intervals compared to respondents who never had infant mortality records. This is in line with study in Spain stating that there were shorter birth intervals in families who had infant mortality records. ${ }^{20}$ Lucas theory stated that if the parents experienced death of a child, then they would try to have another child. This effect is known as a substitute or replacement effect. ${ }^{13}$ The results also showed a significant relation between previous survival and the spacing between births. Median birth intervals was lower on respondents with a record of preceding survival of birth was died (33 months). Respondents with preceding survival of birth was died had the risk 2.15 times more likely to have shorter birth intervals than respondents whose preceding survival of birth was alive. This was due to the need of parents who wanted to immediately replace the dead child in a short time. ${ }^{7,21}$

\section{Conclusion}

Median birth interval is 62 months. The precentage of respondents who have short birth interval is $22.8 \%$. Determinants of short birth intervals include maternal education, age at the last childbirth, ideal family size, contraceptive use, infant mortality records and survival of preceding birth. Women who have the last childbirth at the age $<20$ years have risk 11.1 times of having short birth interval less than three years $(\mathrm{OR}=11.1 ; 95 \% \mathrm{CI}$ $=7.14$ to 16.67$)$. Higher education has the risk 1.51 (1/ $0.66)$ times $(\mathrm{OR}=1.51 ; 95 \% \mathrm{CI}=1.36$ to 1.67$)$, the ideal family size of more than two children has the risk 1.34 times $(\mathrm{OR}=1.34 ; 95 \% \mathrm{CI}=1.21$ to 1.48$)$, traditional contraception has the risk 1.47 times $(\mathrm{OR}=1.47 ; 95 \%$ $\mathrm{CI}=1.18$ to 1.83 ), those who do not use contraceptives have the risk 1.50 times $(\mathrm{OR}=1.50 ; 95 \% \mathrm{CI}=1.35$ to 1.69), infant mortality record has risk 1.68 times 1.50 times $(\mathrm{OR}=1.68 ; 95 \% \mathrm{CI}=1.70-2.73)$, preceding survival of birth died has the risk 2.15 times $(\mathrm{OR}=2.15$; $95 \% \mathrm{CI}=1.43$ to 1.97 ). Highly educated women should be encouraged to reduce short birth intervals. In addition, the optimum birth intervals can be enhanced by improving communication, information and education concerning the maturation of age for marriage, the ideal number of children, then by increasing contraceptive use.

\section{References}

1. Badan Perencanaan Pembangunan Nasional. Report on the achievement of the Millennium Development Goals Indonesia. Jakarta: Badan Perencanaan Pembangunan Nasional; 2010.

2. Badan Pusat Statistik, Kementerian Kesehatan Republik Indonesia, Macro International, Badan Kependudukan dan Keluarga Berencana Nasional. Survei demografi kesehatan Indonesia tahun 2012. Jakarta: Badan Pusat Statistik, Kementerian Kesehatan Republik Indonesia, Macro International, Badan Kependudukan dan Keluarga Berencana Nasional; 2012.

3. United Children's Emergency Fund, World Health Organization, the World Bank, United Nations. Levels \& trends in child mortality 2012. 2012 (cited 10 Januari 2014). Available from: http://www. unicef.org/media/files/Levels_and_Trends_in_Child_Mortality_2012.P df.

4. Rahmadewi, Herartri R. Faktor-faktor yang berhubungan dengan kehamilan berisiko tinggi. Gizi Indonesia. 2011; 34(2): 120-8.

5. Badan Kependudukan dan Keluarga Berencana Nasional. Kamus istilah kependudukan dan keluarga berencana. Jakarta: Badan Kependudukan dan Keluarga Berencana Nasional; 2011.

6. Catalys Consortium, United Stated Agency of International Development. Optimum birth spacing [cited 9 Januari 2014]. Available 
from:www.coregroup.org/storage/documents/smrh_OBSI Overviem.Pdf.

7. Rasheed P, Al-Dabal BK. Perception an practices among urban-based Saudi Arabian women. East Mediterranian Health Journal [serial on internet]. 2007 [cited 9 Januari 2014]; 13(4): 881-92. Available from:www.emro.who.int/emhj/1304/13_4_2007_881_892.pdf

8. Conde-Agudelo A, Bermudez AR, Castano F, Norton M. Effect of birth spacing on maternal, perinatal, infant, and child health : a systematic review of causal mechanism. Studies in Family Planning. 2012[cited 9 Januari 2015]; 43(2): 93-114. Available from: pdf.usaid.gov/ pdf_docs/pnady842.pdf.

9. AA-El-Sherif E, Qayed MH, H-Zarzour A, Fadel K. The effects of birth spacing on infant and child mortality, pregnancy outcomes \& maternal morbidity in Abnoub District, Rural Assiut. 2008 [cited 20 Desember 2014). Available from: https://www.rand.org/content/dam/rand/ pubs/working_papers/2004/RANDWR198.pdf

10. Saraswati E. Faktor kesehatan reproduksi ibu hamil dan hubungannya dengan kejadian bayi berat lahir rendah di Kota Sukabumi tahun 20052006. Kesmas: Jurnal Kesehatan Masyarakat Nasional [serial on internet]. 2006 [cited 20 Januari 2015]; 1(3). Available from: http://jurnalkesmas.ui.ac.id/index.php/kesmas/article/view/304.

11. Prameswari MF. Kematian perinatal di Indonesia dan faktor yang berhubungan, tahun 1997-2003. Kesmas: Jurnal Kesehatan Masyarakat Nasional [serial on internet]. 2007 [cited 20 Januari 2015]; 1(4): 15460. Available from: http://jurnalkesmas.ui.ac.id/index.php/kesmas/article/view/298

12. Rutstein SO. Effect of preceding birth intervals on neonatal, infant, and under-five years mortality and nutritional status in developing countries: evidence from the demographic and health surveys. International Journal of Gynecology and Obstetrics. 2005; 89: 7-24.

13. Davis K, Blake J. Sosial structure and fertility: an analytic framework. Economic Development and Culture Change. 2005 [cited 20 April 2015]; 4 (3): 211-35. Available from:http://www.jstor.org/.

14. Prawirohardjo S. Ilmu kebinanan. Jakarta: Yayasan Bina Pustaka Sarwono Praworohardjo; 2008.

15. Zenebu B, Assegid S, Kassahun W, Gerbaba M. Determinants of inter birth interval among married women living in rural pastoral communities of Southern Ethiopia: a case control study. BMC Pregnancy and Childbirth [serial on internet]. 2013 [cited 2 Januari 2015]; 13: 116. Avalilable from: http://www.biomedcentral.com/1471-2393/13/116

16. Fallahzadeh H, Farajpour Z, Emam Z. Duration and determinants of birth interval in Yazd, Iran: a population study. Iranian Journal of Reproductive Medicine [serial on internet]. 2013 [cited 5 Januari 2015]; 11 (5): 379-84. Available from: http://www.ncbi.nlm.nih.gov/pmc/articles/PMC3941411/
17. Al-Nahedh NN. The effect of sociodemographic variables on child spacing in rural Saudi Arabia. East Mediterrenia Health Journal [serial on internet]. 1999 [cited 12 Januari 2015]; 5: 136-41. Available from: www.ncbi.nlm.nih.gov/pubmed/10793791

18. Baschier A, Hinde A. Determinants of fertility and birth interval in Egypt. Demographic Research [serial on internet]. 2000[cited 12 Januari 2015];16: 54-70. Available from: www.demographicresearch.org/volumes/vol16/3/16-3.pdf

19. Sakait M, Ansari L. Community survey on use of contraceptive methods in Saudi women in Riyadh Region. Journal Family Community Medicine. 1996; 3: 81-97.

20. Polo V, Luna F, dan Fuster V. Determinants of birth interval in a rural Mediterranean Population (La Alpurajarra Spain). Human Biology. 2000; 72: 877-90. The Southeast Asian Journal of Tropical Medicine and Public Health. 2009 [cited 5 Januari 2015]; 40(4): 852-60. Available from: www.tm.mahidol.ac.th/seameo/2009-40-4/274540.pdf

21. Hajian-Tilaki KO, Asnafi N, Aliakbarnia-Omrani F. The patterns and determinants of birth intervals in multiparaous women in Babol, Northern Iran. Southeast Asian journal Tropical Medicine Public Health [serial on internet]. 2009[cited 5 Januari 2015]; 40(4): 852-60. Available from: www.tm.mahidol.ac.th/seameo/2009-40-4/27-4540.pdf

22. Exavery A, Mrema S, Shamte A, Bietsch K, Mosha D, Mbaruku G, et al. Non-adherence of WHO recommended inter-birth interval in Rufiji, Tanzania. BMC Pregnancy Childbirth [serial on internet]. 2012 Dec 13 [cited 12 January 2015]; 12: 152. Available from: http://www.ncbi.nlm. nih.gov/pubmed/23237623.

23. Sutanto PH. Peran faktor komposisional dan faktor kontekstual terhadap jumlah anak yang diinginkan di Indonesia: permodelan dengan analisis multilevel. Jakarta: Pusat Penelitian dan Pengembangan Kependudukan Badan Kependudukan dan Keluarga Berencana Nasional; 2009.

24. Tessema GA, Zeleke BM, Ayele TA. Birth interval and its predictors among married women in Dabat District, Northwest Ethiopia: a retrospective follow up study. African Journal of Reproductive Health [serial on internet]. 2013; 17(2): 39-45.

25. Yohannes S, Wondafrash M, Abera M, Girma, E. Duration and determinants of birth interval among women of child bearing age in Southern Ethiopia. BMC Pregnancy and Childbirth [serial on internet]. 2011 [cited 12 Jan 2015]; 11: 38. Available from: http://www.biomedcentral. com/1471-2393/11/38

26. Bongaarts J, Casterrline J. Fertility transition: is sub-Saharan Africa different?. Population and Development Review [serial on internet]. 2013 [cited 2 Jan 2015]; 38(1):153-68. Available from: http://www.ncbi. nlm.nih.gov/pmc/articles/PMC4011385/ 